\title{
PHILOSOPHICAL VIEWS ON THE VALUE OF PRIVACY
}

\author{
GlenN Negley*
}

Philosophical literature has given scant attention to the problem of privacy as such; the framework of reference within which privacy has so recently and widely become a matter of controversy is a distinctly contemporary one. What has not been discussed, or at least made clear, is why privacy is commonly considered a right or a value to be protected by the law. There is no historical consensus, in philosophy, politics, or law, that it is such a right. Few philosophers would argue that privacy is a "natural" right or that the intrinsic nature of privacy establishes it as a legal right.

To be sure, it seems apparent that the circumstances of existence in modern society are in many ways more restrictive of privacy than conditions in the past; we seem haunted by specters of the organization man, Big Brother, and the omnipresent state. Yet the facts of a changing social and political structure do not themselves attest the badness of that change. Indeed, opinion, judgment, and choice may be exclusively individual and private-and perhaps it is true that in ordinary discourse we generally assume them to be so-but this observation does not establish privacy as an essential, or even desirable, ingredient of opinion and judgment. Any analysis appropriate to modern political and legal structure must take these facts into account, but the facts themselves leave unanswered the question of the status of privacy as a right.

The simple answer to this question is that some degree of privacy is necessary in order to ensure to the individual the possibility of moral choice and action; but this is too simple an answer. Given a definition of moral choice as a right of the individual, one might then proceed to a description of the elements necessary to fulfill the requirements of that definition, in which privacy might or might not be essential. The claim that privacy is a right to be protected by law is, therefore, a question of value discrimination, and the justification of privacy in this context is a problem of moral definition and analysis. The definition of moral choice does not lend itself to factual description, and no amount of word-mongering will make it otherwise. The initial question in moral theory is itself a value question: what ought the moral status of the individual to be?

On the matter of what the moral option of the individual should be, the history of philosophical thought presents such a wide divergence of definitions as in some instances to yield only flat contradictions. The controversy has been further muddled

- A.B. 1930, M.A. I934, Butler University; Ph.D. I939, University of Chicago. Professor of Philosophy, Duke University. Staff Observer, Administrative Staff College, Henley-on-Thames, England, I960 and ig66. Author, Politicaz Authority and Moral Judgment (I965). 
by the almost invariable tendency of proponents of a value judgment to attempt a justification of their definition by purported factual reference. This persistent effort of moralists to establish a value judgment on unwarranted factual grounds-such as by reference to the "natural," the "historical," or the "divine"-has tempted many contemporary thinkers to dismiss the entire controversy as meaningless and to assert a limitation of discourse to that which has warranted factual reference.

The reminder is somewhat fatuous, but necessary, that problems are not resolved by being ignored. The question of how the moral status of the individual is to be defined remains the most profound consideration of our philosophy, for that definition will entail the factual description of the political, social, and legal structure which will meet the requirements of that definition. It is clear that any consideration of whether privacy is indeed a right of the individual will depend upon what definition of the individual we accept. While the question of privacy has rarely been directly discussed in moral thought, it is not surprising that the problem has been lurking on the fringes of all moral, political, and legal theory, awaiting consideration. It is a historical commonplace that problems often await acknowledgment until circumstantial developments force them upon our attention. After centuries of failure to recognize privacy as a factor pertinent to moral and political speculation, we suddenly find ourselves concerned with the right of privacy as one of the most critical problems of contemporary political and legal analysis. The nature of our social structure as it has developed in the recent past forces us to recognize that the privacy which until now has apparently been casually presumed as an ingredient of moral action can no longer be presumed but must be specified.

The history of the recent past has shaped for us, whether we like it or not, a highly centralized, institutional, and increasingly corporate social and political structure. Within the complex of corporate pressures that prescribe the possibilities of action for every man in the modern state, it is a matter of serious concern what latitude of moral discretion is allowed to him. The question is no longer so much one of preventing an invasion of "rights" as that of maintaining conditions that will make the exercise of rights possible. Whether or not it is desirable that the law exercise its function in thus assuring conditions for the realization of privacy is dependent on philosophical definition, not on fact.

The first question, therefore, that must be asked about the right of privacy is whether it is indeed a right at all. Political philosophies present profoundly different views as to the right, or desirability, of private judgment, conscience, or reservation. Italian courts, for example, have this year for the first time allowed that "conscientious objection" may be an acceptable justification for "refusing obedience," and the negative attitude of many political systems to any such claim is well known. The philosophy that describes the political structure as essentially corporate in nature has traditionally derived from, or resulted in, a description of the moral status of the individual that not only denies the right of privacy but designates it a political and 
moral misdemeanor. Hegel's distinction of moralität, as referring to individual private judgment, and sittlichkeit, the definition of obligation in terms of duties defined by the corporate, institutional order, is, of course, the classic example of political philosophy which argues that the claim of privacy is simply an exhibition of caprice, triviality, and irresponsibility. The moral realization of the individual depends entirely upon the degree to which he can identify his interests and duties with the value structure appropriate to the particular corporate order in which he finds himself. Such a view allows little controversy in respect to the right of privacy, since the rights and duties of individuals are determined by the existing corporate orders in which he participates, the highest form of which is the state. Moral discrimination is thus not a function of "private" individual judgment but of historical relativity. The final reduction of privacy is accomplished by this view with the claim that, in the last resort, the individual must accept the value interpretation of an "arbiter" who properly discerns the duties and obligations of the historic moment. ${ }^{1}$

The traditional and casual interpretation of British-American philosophy has been that it is sternly opposed to the corporate view, defining the political structure as a collectivity the legitimacy of which derives from and depends upon the private, individual judgments of those who are comprised in that collectivity. Hence, in this interpretation of our political philosophy, privacy is assumed to be a right justified by utility if not by nature. The right of privacy therefore seems to be an integral and essential ingredient of our political philosophy, a right to be protected by law. Such an analysis is indeed casual, a thoroughly inadequate description of the development of the concept of privacy in our thought, but the persistence of the ill-defined assumption in the face of the facts of contemporary social organization is indicative of the confusion and ambiguity that characterize the idea of privacy.

Perhaps the last philosopher who gave any significant attention to the privacy of the individual was Jeremy Bentham; his strongly expressed view that law was an invasion of privacy that must be justified on the ground of necessary utility was somewhat, but not profoundly, modified by John Stuart Mill. Certainly, our ideas of the function and justification of law have changed rather drastically in the past hundred years, largely under the impact of changing facts of political order. Yet so little attention has been given by philosophers to the intimate relation of law to private judgment and action that one must wonder, on reading much of our moral and philosophical literature, just what kind of amorphous, politically unattached individual these ethicists are talking about. It would not be sensible to argue that Bentham's ideas are immediately applicable to our problems, but it is regrettable that subsequent thought did not recognize the importance of his effort to distinguish

\footnotetext{
${ }^{2}$ One of the clearest statements of this moral view in recent philosophy is that of F. H. BradLEY, Etrocal Studies $(1876$ ), especially chapter V, "My Station and Its Duties." Bradley used the ambiguous term phronemos to describe the moral arbiter.
} 
carefully and distinctly the area of private, individual action and responsibility from that of political and legal liability. ${ }^{2}$ His perception of the problems that would ensue from a confusion of moral responsibility and legal liability provide numerous examples that are relevant to our consideration-for example, his suggestion that any legal effort to enforce "prohibition" would involve such an invasion of privacy as to occasion, on purely utilitarian grounds, more harm than good in the social fabric. ${ }^{3}$

Bentham's break with tradition in moral and political analysis was more profound than his vehement rejection of natural law and natural rights. What emerges in historical retrospect is that Bentham was in fact rejecting a model of analysis that had been inherited from Greek philosophy. That model has been aptly termed by Peter Laslett the "face-to-face society." It was a model singularly inappropriate to the facts of the political state as these facts were beginning to become self-evident in the nineteenth century. Political fact could no longer be brought within the framework of an analysis that assumed a homogeneity - geographic, ethnic, religious, moral -which greatly simplified the problems of moral and legal relationship. Kant had finally recognized this but so belatedly that his brief treatment in Religion Within the Limits of Reason Alone was without appreciable audience. Hegel sought, by a tour de force, reinforced by dubious historical dialectic, to describe a political organism of such homogeneity that its corporate structure would resolve moral and political, individual and social, relations and conflicts. In the assessment of subsequent history, however, with its repeated attempts to achieve the model of corporate order by force, Hegel should not be made the victim of abuse for the excesses we have witnessed in the name of ethnic purity and national aggrandizement.

It was not only in Hegelian thought that there persisted this model of a homogeneous face-to-face social structure in which questions of private judgment and opposition would not arise. Through the eighteenth and up to the middle of the nineteenth century, the communitarian ideal was a dominant model in British, American, and French thought. Persistent in opposition to the rapid-and inevitable -development of more centralized and institutionalized social organization, these communitarians sought in mutuality and homogeneity of purpose to escape the restrictions that such social structure imposed on the individual. There are two profoundly ironical features of this eighteenth century ideal which has exerted such an influence on our thinking. In the first place, the intellectual stubbornness in the use of a model of analysis that was manifestly inappropriate to the emerging social

\footnotetext{
2 The significance that Bentham attached to this distinction was immeasurably clarified by the publication of his sequel to An INTroduction to the Principles of Morals and Legislation (1789). Bentham's moral, political, and legal views can no longer be properly discussed without careful reference to Tres Limits of JuRisprudence Defined (Everett ed. 1945), so ably edited by C. W. Everett; yet this truly monumental discovery seems to have been almost wholly ignored.

a Bentham, AN Introduction to the Principles of Morals and Legislation ch. i7 (i789); Bentham, The Limits of Jurisprudence Defined ch. 21 (Everett ed. 1945).

'Philosophy, Politics and Society ch. to (Laslett ed. 1956).
} 
structure was matched by the continued and often heroic efforts of men to establish and maintain a society fashioned on the face-to-face model. That Robert Owen, for example, whose own successful career as an industrialist should have made him perceptive to the development of an industrialized society, put his hopes and his fortune into such an experiment as New Harmony is almost incredible. A model suited to the small, relatively isolated, artisan city-state of Athens was an anachronism in the eighteenth- and nineteenth-century states of the Western world.

An even stranger charateristic of this philosophy was its rejection of the right of privacy. At a time in history when, as Bentham recognized, the moral status of the individual depended upon protection from an increasingly dominant and intrusive social organization, the communitarians tried to effect a kind of supercorporate organism without even Hegel's historical substance. The rather dismal failure of these efforts is itself an epitaph for a philosophy and a model of analysis no longer appropriate or useful. In some instances, the rejection of privacy took the form of an aggressive attack, as if private judgment and opinion, rather than the social order, were the source of conflict and disorder. The remarkably successful experiment of John Humphrey Noyes, the Oneida community, carried this denial of privacy to the extreme of forbidding monogamous marriage relations, on the ground that these fostered selfishness, jealousy, and strife. It is interesting to note that in all these views, the elimination of privacy as a source of social conflict also eliminated the necessity for any legal processes to arbitrate such conflicts. The lawyer is the first casualty in Utopia.

It is tempting to assess this eighteenth-and nineteenth-century climate of opinion as an exhibition of sheer obtuseness, of patent unrealism in the face of the clearly developing structure of social and political organization. Yet a more generous appraisal would recognize that this was a strenuous, if futile, resistance to an institutionalized social order that threatened so to engulf and submerge the individual that all the values for which man had struggled for two thousand years were endangered. It is difficult to depart from an established pattern of analysis and the value system appropriate to it; the inherited face-to-face value model admitted no accommodation to the new social order but only a total rejection of it. History moved inexorably in the nineteenth century to an intensified and widespread development of the centralized, ubiquitous political organization that had been so strenuously rejected.

Thus, toward the end of the nineteenth century, the thought of the immediate past had provided the ingredients for a fruitful consideration of the problem of privacy in the modern state. Hegel had, on whatever dubious grounds, described the nature of the corporate political order that was rapidly becoming a reality; much was to be gained from his analysis of the institutional structure of that order, even if his value premises were unacceptable. Bentham, refusing to abandon an individualistic value system, had demonstrated that the traditional patterns of political analysis were inadequate to formulate the status of the individual in the political and legal context of the modern state. For their part, the communitarians had rather pathetically 
provided ample evidence, in both thought and practice, that values defined by retrospective nostalgia were stillborn in the modern world.

At this strategic time, there occurred what can only be accounted an intellectual tragedy: the effect of the First World War on Western thought. The formulation of the relation of the individual to the modern state, in the framework of analysis provided by Bentham and Hegel, was indeed well under way at the end of the nineteenth century. The British idealists, strongly influenced by Hegelian thought, were beginning to fashion a new model of political analysis. While they were in a sense "Hegelian," they were also influenced by the individualist tradition of British philosophy." In addition, the principles of Utilitarianism were modified in terms of contemporary social structure, especially by Henry Sidgwick. ${ }^{6}$ Significant also were the definitive and illuminating studies of Kant by Edward Caird. 'Thus, at the turn of the century, there was emerging a model of political analysis and philosophical definition which saw the necessity and the significance of describing individual rights in the context of the modern institutional social structure. The hitherto incompatible values of utilitarianism and corporatism were beginning to find mutual accommodation.

Yet today-and this is the tragedy-one would have to search assiduously to find any mention whatever of this most promising era of our recent philosophical speculation. The work of Sidgwick, Green, and Bosanquet has all but been assigned to oblivion, and the important steps they made in the analysis of rights, and of privacy as a moral right, were totally ignored in subsequent thought; at the moment, we are, philosophically, about where we were in the middle of the nineteenth century. On the other hand, unquestionably these thinkers had a very real impact on the practical politics of the twentieth century, ushering in a new concept of the positive function of the state as responsible for an equality of rights among its citizens. ${ }^{8}$

The depreciation of British idealism has been generally described in terms of a revolt against the Absolute and rejection of metaphysical abstraction. Such an explanation does not account at all for the neglect of Sidgwick, and it bespeaks a meager acquaintance with such work as that of Green. It is seldom noted, but

\footnotetext{
${ }^{5}$ Especially, Bernard Bosanquer, Aspects of the Sociar Problem (1895), The Philosophical Theory of the State (1899), The Value and Destiny of the Individual (1913), Social and Internationat Ideals (IgI ). The most systematic work was that of Thomas Hill Green, Works (R. L. Nettleship ed. 1885).

- The Methods of Ethics (1874), The Principles of Political Economy (2d ed. 1887 ), The EleMENTS of Politics (I89I), and his numerous other writings.

'The Philosophy of Kant (i878), The Critical Philosophy of Immanuer. Kant (r889).

${ }^{8}$ For example, the most influential economic theory of our day, that of John Maynard Keynes, cannot properly be described without reference to the "climate" of the Cambridge school largely generated by Sidgwick, a major influence on the economic theory of Alfred Marshall and through him on that of Keynes.

American pragmatism might also be said to have had more influence in the areas of politics and law than in the realm of philosophy itself. The pragmatists were generally rather casual about the problem of privacy, although Dewey, in his earlier writing, while influenced by his study of Hegel, evidenced serious concern with the ethical problems of an institutionalized social structure. See especially JoHN DEWEY \& JaMES H. TuFts, ETHICS (rg08).
} 
attention needs to be called to the traumatic effect of the First World War. For us who have lived in a continuing state of war, hot and cold, the intellectual deterioration that resulted from the impact of that decline in civilization can be appreciated only in retrospect. The intellectual scapegoat was Hegelian philosophy, as utilized by such chauvinists as von Treitschke-whose interpretation of his views Hegel would surely have disdained. Philosophical enterprise seemed so shocked by historic reality that resolutely and almost uniformly it turned away from reality; from the major concern with the facts of politics and law characteristic of Sidgwick, Green, Bosanquet, and their contemporaries, the postwar philosophers proceeded to the construction of patterns of analysis that were so singular as to be almost incommunicable and that had little or no relevance to the increasing problems of law and politics.

The problem of the political and legal status of the individual in the increasingly corporate structure of all modern states can no longer be ignored. Conditions have thrust upon political and legal institutions the demand for definitions and policies of control. The nature of the political and legal decisions required, such as the assessment of homosexual behavior, of the extent of the right to counsel, or of privacy invasion by electronic means, is a sharp demonstration that the most pressing demand upon our philosophy is for a consideration of the moral and political obligations, duties, and rights within a corporate social order that evidences none of the characteristics of a relatively simple, decentralized, face-to-face society. Our definitions and models of analysis must be appropriate to the facts, although this does not mean at all that they are derivable from those facts. Vague generalities will not suffice, nor will mere reference to "constitutional guarantees," although this is not meant in any sense as a depreciation of constitutional function. There must, for example, be some clear specification as to whether our political philosophy is to enjoin and enforce some degree of homogeneity and agreement in respect to morals and values.

The analytic requirements imposed by the problems of privacy are therefore twofold: the definition of values and the specification of procedures. The first is the task of moral philosophy, reflected in the political function of legislation. The second depends upon legal process, especially as it operates to control the various administrative functions to which the individual is subject. Failure in or neglect of either of these tasks leaves only the alternative of an increasing latitude of arbitrary administrative discretion that can actively circumvent any achievement of values by the individual. Legal control of administrative processes is mandatory, but if it is to be other than a sheer exhibition of force its procedures must be justified. That justification can be provided only by a value judgment as to what the moral and political rights of the individual ought to be. If privacy is defined as an essential requirement for the achievement of morality, then privacy is a right that the law must protect and provide. Modern man is born in chains; only the law can set him free.

\footnotetext{
${ }^{\circ}$ See the strong argument of Sir Patrick Devlin in support of the view that law should enforce an acceptable moral code. Sir Patrick Devitn, The Enforcement of Morals (I959).
} 